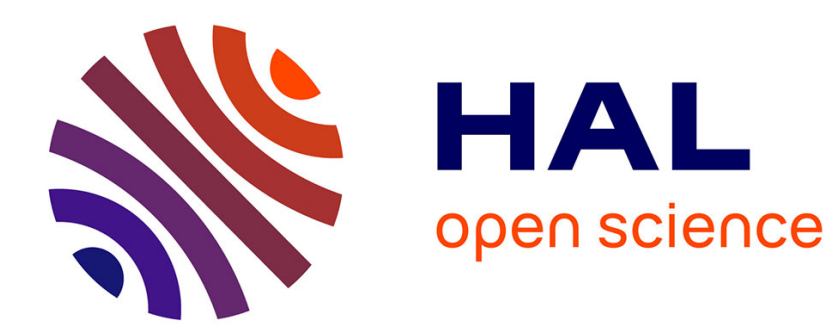

\title{
The seven domains of action for a sustainable Ocean
} Joachim Claudet

\section{To cite this version:}

Joachim Claudet. The seven domains of action for a sustainable Ocean. Cell, 2021, 184 (6), pp.14261429. 10.1016/j.cell.2021.01.055 . hal-03177726

\section{HAL Id: hal-03177726 \\ https://hal.science/hal-03177726}

Submitted on 23 Mar 2021

HAL is a multi-disciplinary open access archive for the deposit and dissemination of scientific research documents, whether they are published or not. The documents may come from teaching and research institutions in France or abroad, or from public or private research centers.
L'archive ouverte pluridisciplinaire HAL, est destinée au dépôt et à la diffusion de documents scientifiques de niveau recherche, publiés ou non, émanant des établissements d'enseignement et de recherche français ou étrangers, des laboratoires publics ou privés. 
Title: The seven domains of action for a sustainable Ocean

Author: Joachim Claudet

Affiliation: National Center for Scientific Research, PSL Université Paris, CRIOBE, USR 3278 CNRSEPHE-UPVD, Maison des Océans, 195 rue Saint-Jacques, 75005 Paris, France

Contact: joachim.claudet@cnrs.fr

Abstract: The Ocean strongly contributes to our well-being but is severely impacted by human activities. Here, I propose seven domains of action to structure our collective efforts toward a scientifically sound, just, and holistic governance of a sustainable Ocean.

\section{Main text:}

\section{The Ocean}

We live on one Planet, which hosts one Ocean. The Ocean is unique; it covers $71 \%$ of our Planet for more than $95 \%$ of its living space, and is distributed in interconnected basins modulated by a range of physical oceanographic processes.

The Ocean is a key piece of our Earth system. Thanks to its abundant phytoplankton, drifting photosynthetic plants, algae and bacteria, it produces between $50 \%$ and $80 \%$ of the planetary oxygen and an estimated $30 \%$ of the oxygen we breathe as humans. It also regulates the climate by storing solar radiation, distributing heat and moisture around the globe, and driving weather systems. In addition, it helps buffer climate change by absorbing up to $93 \%$ of the excess heat from global warming and more than a quarter of the excess $\mathrm{CO} 2$ associated with anthropogenic greenhouse gas emissions over the past half century (Laffoley et al., 2020).

Life appeared in the Ocean 3.7 billion years ago and resulted in far greater evolutionary diversity than on land. Terrestrial species have evolved from marine species, and the most unique taxa are in the oceans, reflected by $39 \%$ of phyla being endemic to the Ocean whereas none are endemic to land and freshwaters (Costello and Chaudhary, 2017).

Marine biodiversity and ecosystem functioning provide tremendous ecosystem services and benefits to human societies, communities, and individual well-being. In addition to oxygen production and climate regulation, Ocean biodiversity supports control of coastal erosion and pollution. Seafood from wild capture fisheries and mariculture is critical for food security (Costello et al., 2020). Many cultures and societies are integrally linked to marine biodiversity and benefit from an Ocean in a good environmental state (Ban et al., 2019). Humans can also derive increased physical and mental health from the Ocean (Fleming et al., 2019). In particular, Ocean diversity has proven to be a rich source of inspiration for drug discovery, with success rates for marine natural products up to 4 times higher than other naturally derived compounds (Sigwart et al., 2021). With up to $30 \%$ to $90 \%$ of marine species undescribed, depending on the estimates, Ocean diversity offers tremendous opportunities for research.

Here, I will first show that while science is pushing the frontiers of Ocean discoveries, it is also revealing that our human footprint spares no component of the Ocean. I will then describe seven domains of action to transform our societies toward a sustainable use of a healthy and productive Ocean, which I synthesized from the specific recommendations made by recent international efforts. 


\section{Further, deeper, smaller: the Ocean's new frontiers}

Although more than eighty percent of the Ocean seafloor is unmapped, unobserved, and unexplored (we have better maps of the Moon and Mars), the last decades have seen an unprecedented pace of Ocean discoveries that push further away from the coasts, dive deeper into the ocean, and observe at smaller organizational scales.

The capacity to combine, at global scales, remote sensing data with physicochemical and biological data collected in-situ from recent Ocean expeditions, such as the Tara Ocean Expeditions (Sunagawa et al., 2020), offers new perspectives to build a more comprehensive knowledge base of global Ocean ecosystems biology. Such endeavors expand our knowledge of biodiversity, organismal interactions, ecological drivers of community structure and genomic proxies for key ecosystem processes, such as the carbon biological pump (Sunagawa et al., 2020). While the field is still in a data-driven, phenomenological discovery phase, it holds promises to gain a holistic understanding of the biodiversity and processes that govern the Ocean.

To start addressing the many unresolved questions on ecosystem functioning in the deep ocean the international scientific community started developing deep-sea observatories in the 1990's. The first observatories were deployed very recently, in the 2010's, and have particular application in studying hydrothermal vents, which were discovered only in the 1970's. Because of these observatories, we are now beginning to understand the functioning of hydrothermal circulation, the key role hydrothermal emissions play in the iron content of the Ocean, the decadal temporal stability of communities, and the existence of behavioral biological rhythms at a species level.

Recent progress in metagenomics allows us to explore ecosystem diversity and function at new organizational scales in the Ocean, such as the microbiome (Bacteria, Archaea, viruses and microeukaryotes). Efforts are dedicated as well on the pelagic or sediment microbiome, or on the organismal external microbiome, which is found to be compositionally distinct from the pelagic microbiome. Such research is expanding rapidly but scientists can already appreciate the central role microbial processes play in climate change regulation.

\section{New impact pathways}

Concomitantly with pushing the frontiers of scientific discoveries, we are realizing the extent of our human footprint on the Ocean, in particular related to climate change. In the last 15 years, six major areas of global concern have been documented (Laffoley et al., 2020): accelerating heating of the Ocean and associated oxygen loss; sea-level rise and linked loss of coastal natural protection; increasing ocean acidification; alterations to wind regimes and perturbations to major ocean currents and upwelling systems; changes in patterns of ocean primary production, species distribution and ecosystems.

Those climate change drivers do not act in isolation but interact with other human drivers, leading to cumulative impacts all across the Ocean, with no place in the Ocean that is not impacted by human activities. While fisheries are themselves impacted by climate change, direct overexploitation of organisms is having the largest relative impact on marine ecosystems (IPBES, 2019). Unsustainable coastal development is destroying valuable coastal habitat formers, such as mangrove forests or coral reefs, which provide protection against coastal erosion and shelter marine resources that can be harvested. Deforestation and land clearing are increasing terrestrial run-offs and land-based pollution. Microplastics are found in organisms down to the deep-sea. Maritime traffic is favoring the spread of non-indigenous species. 
The Ocean economy, or blue economy, is predicted to grow faster than the global economy from 2010 to 2030 (Virdin et al., 2021) and human use of the Ocean for food, material, and space is increasing at a worrying pace (Jouffray et al., 2020). Progress toward achieving international goals for ocean sustainability is lagging behind and concerns are rising on how to ensure this blue growth is sustainable and equitable (Bennett et al., 2021; Reimer et al., 2020).

\section{The sustainable Ocean's domains of action}

The urgent need to identify and implement solutions for sustainable Ocean use has led to many international initiatives promoting innovative or underused solutions, from the recognition of traditional or indigenous sustainable practices to the implementation of innovative finance mechanisms. We are now in year one of the UN Decade for Oceans Science for Sustainable Development and there is an opportunity to harness science for action and real change in the Ocean. Here, I synthesize and structure into seven broad domains of action (Table 1; Figure 1) the recommendations from three recent collective efforts aimed at promoting a scientifically sound, just, and holistic governance for sustainable use of the Ocean (Bennett et al., 2021; Claudet et al., 2020; Lubchenco et al., 2020). In doing so, I hope to convey the message to policy makers, the private sectors, and civil society at large, that the evidence and knowledge base to transform our Ocean into a paragon of sustainability is already there. What is needed now is action. 
Table 1: Domains of action for a sustainable Ocean.

\begin{tabular}{|c|c|c|}
\hline Source & Action & Sustainable Ocean's Domains of Action \\
\hline $\begin{array}{l}\text { Bennett et al. (2021)'s ten risks } \\
\text { and solutions for the ocean } \\
\text { economy. }\end{array}$ & $\begin{array}{l}\text { 1. Recognize and protect resource and spatial tenure and access rights. } \\
\text { 2. Take a precautionary approach to reduce pollution and ensure that environmental burdens are not } \\
\text { placed on marginalized populations. } \\
\text { 3. Minimize the impacts of development on habitats, resources, and ecosystem services. } \\
\text { 4. Consider and safeguard the access rights and livelihoods of small- scale fishers. } \\
\text { 5. Maintain and promote access to marine resources needed for food security and well-being. } \\
\text { 6. Develop policies and mechanisms to foster and ensure the equitable distribution of economic } \\
\text { benefits. } \\
\text { 7. Monitor, mitigate and manage the social and cultural impacts of ocean development. } \\
\text { 8. Recognize, include and promote the equal role of women in the ocean economy. } \\
\text { 9. Recognize and protect human and Indigenous rights. } \\
\text { 10. Develop inclusive and participatory planning and governance processes for ocean development. }\end{array}$ & $\begin{array}{l}\text { Inclusive and holistic governance } \\
\text { Ocean health } \\
\text { Ocean health } \\
\text { Inclusive and holistic governance } \\
\text { Equity and justice } \\
\text { Sustainable economic opportunities } \\
\text { Equity and justice } \\
\text { Equity and justice } \\
\text { Equity and justice } \\
\text { Inclusive and holistic governance }\end{array}$ \\
\hline $\begin{array}{l}\text { Claudet et al. (2020)'s roadmap } \\
\text { for using the UN Decade of } \\
\text { Ocean Science for Sustainable } \\
\text { Development in support of } \\
\text { science, policy, and action. }\end{array}$ & $\begin{array}{l}\text { 1. Stronger integration of sciences. } \\
\text { 2. Ocean-observing systems. } \\
\text { 3. Improved science-policy interfaces. } \\
\text { 4. New partnerships. } \\
\text { 5. New ocean-climate finance system. } \\
\text { 6. Improved ocean literacy and education to modify social norms and behaviors. }\end{array}$ & $\begin{array}{l}\text { Scientific integration } \\
\text { Scientific integration } \\
\text { Inclusive and holistic governance } \\
\text { Inclusive and holistic governance } \\
\text { Financial mechanisms } \\
\text { Literacy and social norms }\end{array}$ \\
\hline $\begin{array}{l}\text { Lubchenco et al. (2020)'s five } \\
\text { priorities for a sustainable ocean } \\
\text { economy. }\end{array}$ & $\begin{array}{l}\text { 1. Manage seafood production sustainably. } \\
\text { 2. Mitigate climate change. } \\
\text { 3. Stem biodiversity loss. } \\
\text { 4. Seize opportunity for economic recovery. } \\
\text { 5. Manage the ocean holistically. }\end{array}$ & $\begin{array}{l}\text { Inclusive and holistic governance } \\
\text { Ocean health } \\
\text { Ocean health } \\
\text { Sustainable economic opportunities } \\
\text { Inclusive and holistic governance }\end{array}$ \\
\hline
\end{tabular}

Note that the assignment of the actions into domains is not exclusive and some actions can overlap domains. 


\section{The Sustainable Ocean's 7 Domains of Action}

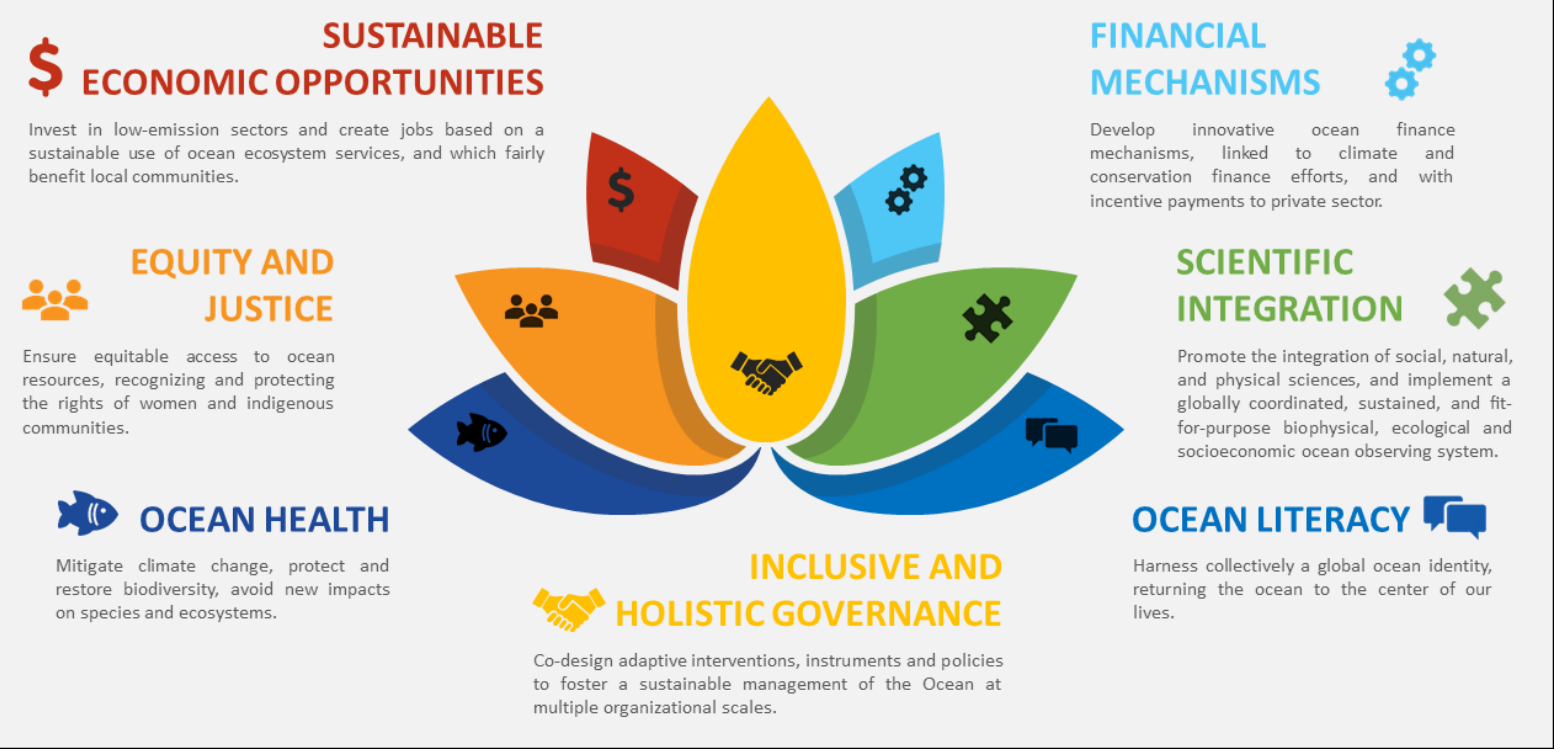

Figure 1: The seven domains of action for a sustainable Ocean

One of the most obvious domains of action is to directly improve Ocean health. All domains of action shall ultimately improve Ocean health, but direct actions should be considered here, such as protecting biodiversity, or restoring it where needed. The use of marine protected areas to do so can help to deliver both ecological and social outcomes while reaching a large number of the targets of the United Nations Sustainable Development Goal dedicated to the Ocean (SDG14) (Reimer et al., 2020). In a rapidly changing world, not only is reducing the existing impacts of human use on species, habitats and ecosystems important, but avoiding new impacts is also key. This Ocean health domain encompasses also actions aimed at mitigating climate change, either by promoting and securing carbon sequestration into the Ocean or by directly reducing greenhouse gas emissions.

A second domain of action for a sustainable Ocean is to ensure social equity and justice is present in all Ocean matters. In particular, care should be given to achieving equitable access to ocean resources, and recognizing and protecting the rights of women and indigenous communities. Conservation or development projects need to be designed with a social justice lens to avoid unexpected cultural harm on the most vulnerable communities (Gill et al., 2019).

A third domain of action is the identification and investment in sustainable economic opportunities. Investments should target low-emission sectors and create jobs based on a sustainable use of marine ecosystem services, ensuring they fairly benefit local communities. In a (soon-to-be) post-COVID world, such opportunities should be prioritized for economic recovery.

The development of innovative ocean finance schemes is a fourth domain of action for a sustainable Ocean. Such mechanisms should be linked to climate and conservation finance efforts and help raise capital investments for the necessary expenditures associated with most transformative actions. With incentive payments to private sector market actors, it should be sustainable in the long term.

Ensuring a strong scientific integration represents a fifth domain of action. The scientific community has a key role to play as a starting point for developing evidence-based solutions that can promote ocean sustainability. Integration should lie at multiple levels. The integration of disciplines within and across social, natural, and physical sciences should be promoted, as well as the recognition and use 
of indigenous local knowledge. Observations need to be integrated too, within a globally coordinated and sustained biophysical, ecological and socioeconomic ocean-observing system. Finally, fit-forpurpose science practice aimed at solving sustainability problems needs to be adapted to and integrated with the ecological, economic, and sociocultural contexts, including regulatory frameworks and political realities, in which the sustainability problems to solve lie.

Improved ocean literacy and education is the sixth domain of action. It should stimulate new models for ocean action. We should collectively harness a global ocean identity, returning the ocean to the center of our lives, and ensure that that identity is preserved for future generations. Such a change of perspective can help develop new social norms that will in turn create new conditions that incentivize governments, the private sector, and individuals to make necessary changes to their behavior (Claudet et al., 2020).

Inclusive and holistic governance is the last domain of action. Co-produced, adaptive instruments to foster sustainable use of ocean resources at multiple organizational scales are both supported by the six previous domains and provide the enabling conditions for their realizations. Science should play a critical role in informing policies but effective science-policy interfaces are scant, hindered by complex policy processes and the distinct methods and epistemologies of science and policy. Science should not compete with other forces shaping the policy-making space but instead co-produce evidence with them, to ensure recommendations can better be transferred into action (Claudet et al., 2020). The private sector, a major actor of current unsustainable trajectories of ocean use, is also increasingly recognized as having the capacity to bend these trajectories by taking on the mantle of corporate biosphere stewardship (Virdin et al., 2021). This can also foster the development of more holistic, multi-sectoral policies. Together with science and the private sector, involving civil society, indigenous and local communities in more inclusive, participatory, and decentralized governance arrangements can induce the behavioral change needed to result in the development and ownership of more sustainable practices.

\section{Conclusion}

The Ocean is unique. It was home of the birth of life on our Planet and currently supports vital and valuable services and contributions to human well-being. Preserving the Ocean is preserving our way of life. Now that there is no place in the Ocean that is not impacted by our activities, we should collectively place it at the center of our lives and action the levers that are already identified to start a new era of a sustainable relationships with our Ocean.

\section{References}

Ban, N.C., Gurney, G.G., Marshall, N.A., Whitney, C.K., Mills, M., Gelcich, S., Bennett, N.J., Meehan, M.C., Butler, C., Ban, S., et al. (2019). Well-being outcomes of marine protected areas. Nat. Sustain. 2, 524-532.

Bennett, N.J., Blythe, J., White, C.S., and Campero, C. (2021). Blue growth and blue justice: Ten risks and solutions for the ocean economy. Mar. Policy 125, 104387.

Claudet, J., Bopp, L., Cheung, W.W.L.L., Devillers, R., Escobar-Briones, E., Haugan, P., Heymans, J.J., Masson-Delmotte, V., Matz-Lück, N., Miloslavich, P., et al. (2020). A Roadmap for Using the UN Decade of Ocean Science for Sustainable Development in Support of Science, Policy, and Action. One Earth 2, 34-42.

Costello, M.J., and Chaudhary, C. (2017). Marine Biodiversity, Biogeography, Deep-Sea Gradients, and Conservation. Curr. Biol. 27, R511-R527.

Costello, C., Cao, L., Gelcich, S., Cisneros-Mata, M.Á., Free, C.M., Froehlich, H.E., Golden, C.D., Ishimura, G., Maier, J., Macadam-Somer, I., et al. (2020). The future of food from the sea. Nature 588, 95-100.

Fleming, L.E., Maycock, B., White, M.P., and Depledge, M.H. (2019). Fostering human health through ocean sustainability in the 21st century. People Nat. 1, 276-283. 
Gill, D.A., Cheng, S.H., Glew, L., Aigner, E., Bennett, N.J., and Mascia, M.B. (2019). Social Synergies, Tradeoffs, and Equity in Marine Conservation Impacts. Annu. Rev. Environ. Resour. 44, 347-372.

IPBES (2019). Summary for policymakers of the global assessment report on biodiversity and ecosystem services of the Intergovernmental Science-Policy Platform on Biodiversity and Ecosystem Services.

Jouffray, J.-B., Blasiak, R., Norström, A. V., Österblom, H., and Nyström, M. (2020). The Blue Acceleration: The Trajectory of Human Expansion into the Ocean. One Earth 2, 43-54.

Laffoley, D., Baxter, J.M., Amon, D.J., Claudet, J., Hall-Spencer, J.M., Grorud-Colvert, K., Levin, L.A., Reid, P.C., Rogers, A.D., Taylor, M.L., et al. (2020). Evolving the narrative for protecting a rapidly changing ocean, post-COVID-19. Aquat. Conserv. Mar. Freshw. Ecosyst. aqc.3512.

Lubchenco, J., Haugan, P.M., and Pangestu, M.E. (2020). Five priorities for a sustainable ocean economy. Nature 588, 3032.

Reimer, J.M., Devillers, R., and Claudet, J. (2020). Benefits and gaps in area-based management tools for the ocean Sustainable Development Goal. Nat. Sustain.

Sigwart, J.D., Blasiak, R., Jaspars, M., Jouffray, J.-B., and Tasdemir, D. (2021). Unlocking the potential of marine biodiscovery. Nat. Prod. Rep.

Sunagawa, S., Acinas, S.G., Bork, P., Bowler, C., Acinas, S.G., Babin, M., Bork, P., Boss, E., Bowler, C., Cochrane, G., et al. (2020). Tara Oceans: towards global ocean ecosystems biology. Nat. Rev. Microbiol. 18, 428-445.

Virdin, J., Vegh, T., Jouffray, J.-B., Blasiak, R., Mason, S., Österblom, H., Vermeer, D., Wachtmeister, H., and Werner, N. (2021). The Ocean 100: Transnational corporations in the ocean economy. Sci. Adv. 7, eabc8041. 